\title{
Implementing Andragogy In Indonesian Theological Schools
}

\author{
Leonard Sumule ${ }^{1 *}$
}

\author{
1) Alumni Biola University \\ *Penulis korespondensi: leo.sumule@gmail.com
}

Received: 15 January 2018/Revised: 16 March 2018 /Accepted: 20 March 2018

\begin{abstract}
Most churches in Indonesia consider the term "Sunday School" as a Christian education program that is only for children. That is why "adult Sunday School" is a term that is rarely heard in Indonesia. However, Christian education for adults is necessary in the church. This lack of attention to adults in Christian education is the underlying reason for this article. This article addresses Malcolm Knowles' concern about the importance of androgogy, the method and practice of teaching adult learners, in institutions that provide adult education. The andragogical education theory proposed by $\mathrm{M}$. Knowles is applicable cross-culturally. By understanding the unique needs of adults in the learning environment, the approach in recruiting adults to take part in a structured learning environment will be more effective and productive. The implementation of this approach in theological school programs may eventually result in increased support for adult Christian education in churches in Indonesia. By using Malcolm Knowles's andragogy method, adults will experience learning derived from "process design" rather than sourced from a "content plan". Through the experience of designing the educational process, adults will participate in an atmosphere of mutual respect through discovering and contributing their knowledge and experience with each other in the learning environment.
\end{abstract}

Keywords: andragogy, pedagogy, adult education, experience, participation, contribution

Sebagian besar gereja-gereja di Indonesia menganggap Sekolah Minggu sebagai program pendidikan Kristen hanya untuk usia anak-anak. Itulah sebabnya istilah sekolah minggu dewasa atau adult Sunday School merupakan istilah yang jarang terdengar. Padahal, pendidikan Kristen untuk orang dewasa sangat diperlukan di dalam gereja. Kurangnya perhatian terhadap pendidikan Kristen bagi orang dewasa inilah yang mendasari penulisan artikel ini. Tulisan ini mengetengahkan perhatian Maclom Knowles tentang pentingnya Andragogi dalam institusi yang menyediakan pendidikan orang dewasa. Teori pendidikan andragogi yang dikemukakan oleh $\mathrm{M}$. Knowles ini dapat diimplementasikan dalam setiap budaya. Dengan memahami dan mengerti keunikan orang dewasa dalam belajar, maka pendekatan dalam perekrutan orang dewasa untuk memiliki struktur pengalaman belajar akan lebih efektif dan produktif, terutama dalam pelayanan di institusi pendidikan teologi yang akhirnya akan 
menunjang pendidikan Kristen orang dewasa di gereja-gereja di Indonesia. Dengan memakai metode andragogi yang dikemukakan oleh Maclom Knowles, orang dewasa akan belajar bukan seperti dalam pedagogy yang bersumber pada "content plan", tetapi bersumber pada "process design." Dalam mendesain proses pendidikan yang ada, orang dewasa akan turut berpartisipasi dalam suasana saling menghormati lewat menemukan dan memberi kontribusi pengetahuan dan pengalaman mereka terhadap peserta didik dewasa yang lain.

Kata kunci: andragogi, pedagogi, pendidikan orang dewasa, pengalaman, partisipasi, kontribusi.

\section{Introduction}

Most Christians in Indonesia, when asked about the term "school" or "Sunday school", they always think that those terms are addressed to children's education. Even the term "Adult Sunday School", which is a very familiar sound in the ears of Christians in America, is not heard of among the churches in Indonesia. Why? According to the Christians in Indonesia, Sunday School is always intended for children. It is also carried in general education. That is why the term education is always directed to the education of the children or young persons rather than to adult education.

Since Indonesia was colonized by the European countries (by the Dutch for three and a half centuries and the British for three and a half years), the school education system in Indonesia is strongly influenced by the European education model. ${ }^{1}$ However, "The Dutch system was gradually replaced by the American system through the influence of faculty members who were educated in the United States." 2 That is why educational books that exist in Indonesia are still mostly focused on pedagogy. ${ }^{3}$ Ronda acknowledges that there is a change in the pedagogy system in Indonesia. However, Ronda (2007) does not mention of the term "andragogy" in his dissertation.

${ }^{1} \mathrm{~J}$. Forshee, Culture and customs of Indonesia (Westport, CT: Greenwood Press, 2006); C. Brown, A short history of Indonesia: The unlikely nation? (Singapore: South Wind Productions, 2003); R. L. Dixon, The role of the teacher and student in the transmission of the value of responsibility in the teaching/learning process in Indonesian higher education (Doctoral dissertation, 1992), retrieved from ProQuest Dissertations and Theses (Accession Order No. AAT 9302774).

${ }^{2} \mathrm{~S}$. Soeherman, The relationships of critical thinking skills, critical thinking dispositions, and college experiences of theological students in Indonesia. (Doctoral dissertation, 2010), 16, retrieved from ProQuest Dissertations and Theses (Accession Order AAT 3448370).

${ }^{3}$ Daniel Ronda, The perspectives of students and theological educators on good teaching: A look at theological education in Indonesia. (Doctoral dissertation, 2007), retrieved from ProQuest Dissertations and Theses (Accession Order No. AAT 3275109). 
Regarding pedagogy in Indonesia, Ronda writes,

[E]ducational pedagogy has been changed in Indonesia and more schools are applying student-centered learning. However, engaging with student activities alone is not enough. Teaching involves community. The community, such as parents and churches, should take a more active role in the education of their students by helping school management be more transparent and accountable in both the teaching and learning processes. ${ }^{4}$

According to Knowles, Holton \& Swanson (2005) schools in Europe in the seventh century directed teaching specifically to children to prepare the young boys to become priests. This kind of education survived until the twentieth century and became the basis and the foundation of educational system in America. Knowles et al. explain,

Since the indoctrination of students in the beliefs, faith, and rituals of the church was the principal mission of these teachers, they developed a set of assumptions about learning and strategies for teaching that came to be labeled pedagogy, literally meaning "the art and science of teaching children" (derived from the Greek words paid, meaning "child," and agogus, meaning "leader of"). ${ }^{5}$

Malcolm S. Knowles, "the Father of Andragogy in the United States," ${ }^{\prime 6}$ reveals that although the education of adults had been a concern to people for a long time, but the writings respecting adult education emerged in the early 1960s. Therefore, Knowles asserts," The adult learner has indeed been a neglected species,"7 This is also the reason why Knowles (1990) wrote a book which titled, The adult leaner: A neglected species. Knowles (1984) acknowledges that during two decades between 1960 and 1980, "[People] gained more knowledge about the unique characteristics of adults as learners and their learning processes than had been accumulated in all previous history." 8

Knowles (1990) realizes that there is actually a lot of information that can be obtained if we study the lives of famous teachers in the

${ }^{4}$ Ronda, 42.

${ }^{5}$ M. S. Knowles, E. F. Holton, \& R. A. Swanson, The adult learner: The definitive classic in adult education and human resource development, $6^{\text {th }} \mathrm{ed}$. (San Diego, CA: Elsevier, 2005), 36.

${ }^{6}$ Ibid., v.

${ }^{7}$ M. S. Knowles, The adult leaner: A neglected species, $4^{\text {th }}$ ed. (Huston, TX: Gulf Publishing Company, 1990), 27.

${ }^{8}$ M. S. Knowles \& Associates, Andragogy in action: Applying modern principles of adult learning (San Francisco, CA: Joessey-Bass Inc, 1984), 6. 
ancient time. Knowles acknowledges that all of well-known teachers at that time were not for children but for adults. Knowles, therefore, writes, "Confucius and Lao Tse of China; the Hebrews Prophets and Jesus in Biblical times; Aristotle, Socrates, and Plato in ancient Greece; and Cicero, Evelid, and Quintillian in ancient Rome - were the resource persons all teachers of adults." ${ }^{\prime}$

Most likely why the education of adults was not a big concern is because a lot of people thought that adults can not learn as well as young people learn. There is even a term that is used on Main Street America as a negative stereotype that, "You can't teach on old dog new tricks."10

That is why this paper will attempt to explain the significance of the theory of andragogy and how the theory has influenced adult learning at large. Furthermore, this paper also tries to see whether the andragogy principles can be utilized at theological schools in Indonesia.

\section{Andragogy}

The term "andragogy" derives from the Greek aner, meaning man." Although Malcolm S. Knowles is always called "The Father of Andragogy in United States," the term "andragogy" is not his invention. However, he originally defined "andragogy" as "the art and science of helping adults learn." ${ }^{2}$ Nowadays, andragogy is "an umbrella term that has been widely adopted around the world as the primary concept for the education of adults." ${ }^{3}$ Knowles himself admits, "I have borrowed the label 'andragogy' from my European colleagues." ${ }^{14}$ Knowles et al. (2005) explain,

A Dutch adult educator, Ger van Enckevort, has made an exhaustive study of the origins and use of the term andragogy. A summary of his findings follows. The term (andragogic) was first coined, so far as he could discover, by a German grammar school teacher, Alexander Kapp, in $1833 .{ }^{15}$

${ }^{9}$ Knowles, The adult leaner: A neglected species, 27.

${ }^{10}$ H. B. Long, Understanding Adult Learners. In M. W. Galbraith, ed., Adult learning methods: A guide for effective instruction (Malabar, FL: Roberte E. Krieger Pub, 1990), 23.

${ }^{11} \mathrm{P}$. Jarvis, Adult education and lifelong learning: Theory and practice, $3^{\text {rd }}$ Edition (New York, NY: Routledge Falmer, 2004), 125.

12 Ibid., 125.

${ }^{13}$ R. A. Holt, An analysis of contemporary adult learning theories and the implications for teaching in the local church for spiritual maturity. (Doctoral dissertation, 2010), 63, retrieved from ProQuest Dissertations and Theses (Accession Order AAT 3431780).

${ }^{14}$ M. S. Knowles, The modern practice of adult education: Andragogy versus pedagogy (New York, NY: Association Press, 1970), 16.

${ }^{15}$ M. S. Knowles, E. F. Holton, \& R. A. Swanson, The adult learner: The definitive classic in adult education and human resource development, 59. 
After doing his own research and also learning from pioneering theorists, ${ }^{16}$ Knowles et al. established the foundation of modern adult learning theory, namely:17

1. Adults are motivated to learn as they experience needs and interests that learning will satisfy; therefore, these are the appropriate starting points for organizing adult learning activities.

2. Adults' orientation to learning is life-centered; therefore, the appropriate units for organizing adult learning are life situations, not subjects.

3. Experience is the richest resource for adult learning; therefore, the core methodology of adult education is the analysis of experience.

4. Adults have a deep need to be self-directing; therefore, the role of the teacher is to engage in a process of mutual inquiry with them rather than to transmit his or her knowledge to them and then evaluate their conformity to it.

5. Individual differences among people increase with age; therefore, adult education must make optimal provision for differences in style, time, place and pace of learning.

According to Knowles that it was interesting to him what he has learned from Lindeman's book The meaning of adult education. He found that "[Lindeman] did not dichotomize adult versus youth education, but rather adult versus 'conventional' education, thus implying that youth might learn better, too, when their needs and interests, life situations, experience, self-concepts, and individual differences are taken into account". ${ }^{18}$ This means that the principles of andragogy not only can be applied toadults' learning butcan also beimplemented in a youth education at large.

\section{Pedagogy versus Andragogy}

In order to understand the difference between Pedagogy and Andragogy, Knowles et al. (1984) attempt to explain these different approaches in designing and operating pedagogical and andragogical educational programs. Knowles \& Associates contrast, "The basic format

${ }^{16}$ H. Sorenson, Adult abilities (Minneapolis, MN: University of Minnesota Press, 1938); E. L. Thorndike, Adult learning (New York, NY: Macmillan, 1928); E. C. Lindeman, The meaning of adult education (New York, NY: New Republic, 1926).

${ }^{17}$ M. S. Knowles, E. F. Holton, \& R. A. Swanson, The adult learner: The definitive classic in adult education and human resource development, 39-40.

${ }^{18}$ Knowles, The modern practice of adult education: Andragogy versus pedagogy, 32. 
of the pedagogical model is a content plan"19 whereas "The basic format of the andragogical model is a process design." 20

Knowles \& Associates differentiate the pedagogical model as traditional learning in contrast to the andragogical model as a new approach to learning. To understand the difference between these two models, we can see in the following table, which I adapt from the description of Knowles \& Associates. ${ }^{21}$

Table 1. The Pedagogical Model and The Andragogical Model

\begin{tabular}{|c|c|c|c|}
\hline & & $\begin{array}{l}\text { The Pedagogical Model } \\
\text { (Traditional Learning) }\end{array}$ & $\begin{array}{l}\text { The Andragogical Model (A } \\
\text { New Approach to Learning) }\end{array}$ \\
\hline 1 & $\begin{array}{l}\text { The concept of } \\
\text { the learner }\end{array}$ & $\begin{array}{l}\text { The learner is, by } \\
\text { definition, a dependent } \\
\text { personality. }\end{array}$ & The learner is self-directing. \\
\hline 2 & $\begin{array}{l}\text { The role of the } \\
\text { learner's } \\
\text { experience }\end{array}$ & $\begin{array}{l}\text { Leaners enter into and } \\
\text { educational activity with } \\
\text { little experience. }\end{array}$ & $\begin{array}{l}\text { Adults enter into an educational } \\
\text { activity with both a greater } \\
\text { volume and a different quality of } \\
\text { experience from youth. }\end{array}$ \\
\hline 3 & $\begin{array}{l}\text { The readiness } \\
\text { to learn }\end{array}$ & $\begin{array}{l}\text { Students become ready to } \\
\text { learn what they are told. } \\
\text { Readiness is largely a } \\
\text { function of age. }\end{array}$ & $\begin{array}{l}\text { Adults become ready to learn } \\
\text { when they experience a need to } \\
\text { know or do something in order to } \\
\text { perform more effectively in some } \\
\text { aspect of their lives. }\end{array}$ \\
\hline 4 & $\begin{array}{l}\text { The orientation } \\
\text { to learning }\end{array}$ & $\begin{array}{l}\text { Students enter into an } \\
\text { educational activity with } \\
\text { a subject-centered } \\
\text { orientation to learning. }\end{array}$ & $\begin{array}{l}\text { Adults enter an educational } \\
\text { activity with a life-centered, task- } \\
\text { centered, or problem-centered } \\
\text { orientation to learning. }\end{array}$ \\
\hline 5 & $\begin{array}{l}\text { The motivation } \\
\text { to learn }\end{array}$ & $\begin{array}{l}\text { Students are motivated } \\
\text { primarily by external } \\
\text { pressure from parents } \\
\text { and teachers, } \\
\text { competition for grades, } \\
\text { the consequences of } \\
\text { failure, and the like. } \\
\end{array}$ & $\begin{array}{l}\text { Besides external motivators - a } \\
\text { better job, a salary increase, etc., } \\
\text { adults are motivated by self- } \\
\text { esteem, recognition, better } \\
\text { quality of life, greater self- } \\
\text { confidence, self-actualization, } \\
\text { etc. }\end{array}$ \\
\hline
\end{tabular}

Merriam, Caffarella, \& Baumgartner (2007) attempt to explain six assumptions in which Knowles based his theory of andragogy. Merriam et al. (2007) elaborate, "Knowles originally advanced the following four assumptions: ${ }^{22}$

${ }^{19}$ Knowles \& Associates, Andragogy in action: Applying modern principles of adult learning, 13.

${ }^{20}$ Ibid., 14.

${ }^{21}$ Ibid., 8-12.

${ }^{2}$ S. B. Merriam, R. S. Caffarella, \& L. M. Baumgartner, Learning in adulthood: A comprehensive guide (San Francisco, CA: Jossey-Bass, 2007); M. S. Knowles, The modern practice of adult education: Andragogy versus pedagogy, 44-45. 
1. As a person matures, his or her self-concept moves from that of a dependent personality toward one of a self-directing human being.

2. An adult accumulates a growing reservoir of experience, which is a rich resource for learning.

3. The readiness of an adult to learn is closely related to the developmental task of his or her social role.

4. There is a change in time perspective as people mature - from future application of knowledge to immediacy of application. Thus, and an adult is more problem centered than subject centered in learning.

In later publications, Knowles also referred to a fifth and a sixth assumption:

5. The most potent motivations are internal rather than external. ${ }^{23}$

6. Adults need to know why they need to learn something."24

Based on these six assumptions the educational programs for adults can be designed. From each assumption we can have many implications for learning programs that implement and evaluate our learning activities with adults. As an example, Knowles \& Associates explain that since an adult is "a self-directing human being" (the first assumption) it is very important to have a good climate setting for both the physical environment and the psychological climate. Knowles acknowledges, "My preference is to have [adults] sitting around tables, five or six to a table. I also prefer meeting rooms that are bright and cheerful with colorful decor." 25

In addition, according to Knowles \& Associates, that the psychological climate is even more important for adult learning as compare to the physical environment. There are seven characteristics of a psychological climate that conducive for adult learning environment, namely:26

1. A climate of mutual respect - people are more open to learning when they feel respected.

2. A climate of collaboration - since peers are the richest resources for learning, competitiveness makes those resources inaccessible.

3. A climate of mutual trust - people learn from those they trust more than from those they mistrust.

4. A climate of supportiveness - people learns better when they feel supportive rather than judged or threatened. learning, 12 .

${ }^{23}$ M. S. Knowles \& Associates, Andragogy in action: Applying modern principles of adult

${ }^{24}$ Ibid., 84.

${ }^{25}$ Ibid., 15.

${ }^{26}$ Ibid., 15-17. 
5. A climate of openness and authenticity - when people feel free to be open and natural, to say what they really think and feel, they are more likely to be willing to examine new ideas and risk new behavior than when they feel the need to be defensive.

6. A climate of pleasure - learning should be one of the most pleasant and gratifying experiences in life.

7. A climate of humanness - the more people fell that they are being treated as human beings, the more they are likely to learn.

\section{The Practical Implementation of Andragogical Approach to Adult Leaners}

In her book Learning to listen, learning to teach: The power of dialogue in educating adults, Jane Vella gives credit to many previous adult educators including Malcolm Knowles as her teachers. In this book, Vella attempts to implement the andragogical principles introduced by Knowles. It is interesting to know that Malcolm Knowles wrote the foreword for Vella's book. Knowles appreciates Vella's amazing contribution for adult learning around the world. He expresses,

Jane Vella is one of the most gifted adult educators I have known. She has discovered and mastered the fundamental concepts of adult learning and applies them with flair, imagination, and loving, tender care. But she is more than a gifted teacher-she is also a gifted storyteller. ${ }^{27}$

Even though Knowles is known as "The Father of Andragogy in United Stated", who has written eighteen books on adult education, with a humble heart he admitted that he was surprised to learn more about the theory and practice of adult education from Vella's book. Moreover, from Vella's book, Knowles acquires more information about other people and cultures that have implemented the principles of andragogical theories successfully. He acknowledges,

I am also delighted and rewarded by how much I learned about the people and cultures of lands I have never visited-northern Ethiopia, Tanzania, Indonesia, the Maldives, Nepal, El Salvador, Zimbabwe, Bangladesh. I understand our world better now; I am a more competent global citizen. ${ }^{28}$

In her book, Vella proposes a strong emphasis on "the power of dialogue" in educating adults. According to Vella, dialogue or discussion

\footnotetext{
${ }^{27}$ J. K. Vella, Learning to Listen, Learning to Teach: The Power Of Dialogue In Educating Adults, Revised Edition (San Francisco, CA: Jossey-Bass, 2002), vii.

${ }^{28}$ Ibid., vii.
} 
is very crucial in educating adults because "adults have enough life experience to be in dialogue with any teacher about any subject and will learn new knowledge, attitudes, or skills best in relation to that life experience." ${ }^{29}$ Knowles et al (2005) recognize the necessity of dialogue in adult learning as well. They point out, "The Greeks invented what we now call the Socratic dialogue, in which the leader or a group member poses a question or dilemma and the group members pool their thinking and experience to seek an answer or solution." ${ }^{30}$

Since dialogue is important in adult learning, Knowles et al (2005) affirm the relationship between dialogue and experiential learning theory established by David Kolb. Knowles et al. (2005) write, "Kolb (1984) points out that learning is a continuous process grounded in experience, which means that all learning can be seen as relearning. This is particularly true for adults who have such a large reservoir of experiences." 31

In addition, Wilson \& Burke (1989) also discuss that there is connection between dialogue and life experience in learning in Kolb's theory. They elaborate,

Kolb maintains that learners will not learn if they are not open to experience. Nor will learning occur if the experience directly confronts the belief systems of the learners. Therefore, it is up to the educator to implant new ideas and to modify old ones that learners have without contradicting existing beliefs. This is accomplished as the educator guides the leaners in bringing forth their beliefs, testing them, and then guiding the learners in integrating new ideas with old ones. Thus the educator is a manager of the learning process and environment since conditions must be created in which both personal and social knowledge is created. ${ }^{32}$

Based on Knowles's foundation stones of modern adult learning theory, that is, "Experience is the richest resource for adult's learning; therefore, the core methodology of adult education is the analysis of experience," 33 Vella (2002), a well-known adult educator, has implemented her twelve principles for effective adult learning through "the power of dialogue". From her teaching and travelling in "twelve very different situation around the world" 34 and her seventy years experience

\section{${ }^{29}$ Vella, 3.}

${ }^{30}$ M. S. Knowles, E. F. Holton, \& R. A. Swanson, The adult learner: The definitive classic in adult education and human resource development, 35.

${ }^{31}$ Ibid., 194.

32 A. L. Wilson, \& L. Burket, 1989, What Makes Learning Meaningful? ERIC, EBSCOhost (accessed December 8, 2011), 3.

${ }^{33}$ Knowles, The adult leaner: A neglected species, 31.

${ }^{34}$ Vella, xvii. 
in teaching, Vella has discovered that these principles are applicable across cultures. These twelve principles are as follow: 35

1. Need assessment: participation of the learners in naming what is to be learned.

2. Safety in the environment and the processes.

3. Sound relationships between teacher and learner and among learners.

4. Sequence of content and reinforcement.

5. Praxis: action with reflection or learning by doing.

6. Respect for learners as decision makers.

7. Ideas, feeling, actions: cognitive, affective and psychomotor aspects of learning.

8. Immediacy of learning.

9. Clear roles and role development.

10. Teamwork and use of small groups.

11. Engagement of learners in what they are learning.

12. Accountability: who do they know they know?

For the purpose of this paper, not all of these aforementioned principles are elaborated. I will only focus on the third and sixth principles as Vella told her narratives working with Indonesian students both in an Indonesia setting and in an American school setting.

\section{Implementing Andragogical Principles with An Indonesian Student}

It is known in America that "Time is Money," however, for Indonesian people "Time is Friendship." Therefore, Vella took her best effort when she was on the island of Java, Indonesia, to do a two-week training of Save the Children staff. On this occasion, Vella took the time to get to know her students. There she met with Margie Ahnan, a gifted artist and physician. Two years later Ahnan had an opportunity to study in America. Besides studying at a large school of public health, Ahnan also had an opportunity to attend a three-month program at Jubelee Popular Education Center (JPEC) in Raleigh, North Carolina, conducted by Jane Vella.

Vella acknowledges "the power of sound relationships in enhancing adults' potential learning." 36 Therefore, she endeavors to build a world of equity between professor and leaners. She writes, "The quality of the relationship between teachers and adult learners is the central principle in this story" ${ }^{37}$ Their teaching and learning process during the three months program at JPEC can be summarized as follows:

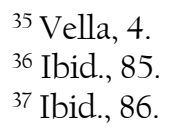


1. They designed the program together starting with the draft presented by Jane Vella.

2. They chose reading materials together which would be utilized for daily seminars through dialogue regarding the reading and the learning.

3. There was no "professor" during the dialogues. The authors of the books did the teaching.

4. Through sound relationship, the role distinction of teacher-student began to dissolve. "We were friends learning together."38

5. The relaxed atmosphere during the program allowed them to disagree in agreement. "There is the opportunity for disagreement in a friendly relationship that invites honest opposition... In such a relationship we could address errors in judgment and logic, challenge incomplete thinking, and defend and celebrate cultural distinctions." ${ }^{39}$

Through this memorable experience with Vella at JPEC, Ahnan was challenged to introduce this kind of andragogical principle into her formal school setting in Indonesia. The principle of Andragogy that Dr. Ahnan has learned and experienced was,

[A] sound relationship between mentor and adult learner is productive learning. Within that relationship, the variable we can control are time, affirmation, mutual respect, open dialogue, open questions that invite dialogue, engagement in significant work, role clarification, responsibility, and immediate response to questions and issues that are raised. ${ }^{40}$

After finishing her post graduate study in America, Ahnan went back to Indonesia where she began to transfer her knowledge and skill in her workplace. What she has experienced and learned from JPEC was very applicable to Indonesian culture. She utilized dialogue education in teaching public health nurses. Ahnan explains, "These nurses are now sharing their own strengths, using all the principles and practices with the women. The tigers are loose in Java!". ${ }^{41}$

\section{Implementing Andragogical Principles in Theological Schools in Indonesia}

Dixon (1992), Ronda (2007) \& Soeherman (2010) discuss in their dissertations that most higher education settings in Indonesia utilize the traditional model of teaching where teachers lecture and students are expected to memorize the content of the courses for their examinations.

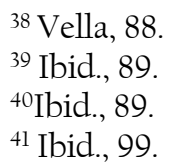


Consequently, "This traditional type of teaching is practiced [also] in most theological schools in Indonesia". ${ }^{42}$ Concerning the number of theological schools in Indonesia, Ronda reports,

Today, more than one hundred theological schools exist in Indonesia. Thirty-three theological schools (covering up to 70 percent of total students) are members of PERSETIA (Association of Theological Schools in Indonesia). This association is supported by major mainline churches, and some evangelical churches are also involved. Other theological schools belong to PASTI (Evangelical Theological Association) and PERSATPIM (Pentecostal Theological Association). Some evangelical theological schools have dual membership. ${ }^{43}$

Ronda suggests that in order to have a conducive teaching and learning environment, a teacher needs to move from a teacher-centered classroom to student-centered learning. Therefore, the educators need to be open to receive and learn new methods of teaching that can encourage the students to "develop their critical thinking ability" 44 . It means, besides utilizing pedagogical methods, theological schools in Indonesia need to implement andragogical principles in their teaching and learning activities.

In chapter six of Andragogy in action by Knowles \& Associates (1984), Eugene Trester reports how the andragogical theory of adult learning was implemented in Biblical Andragogy Clinic, headquartered in Mississauga, Ontario, Canada. Trester lists the special features of Andragogy clinic, namely, "(1). The challenge to religious educators of adult learnes, (2). Focus on learning, not teaching, (3). Formation of learning communities, and (4). Leadership training through Facilitator's Clinics." 45

Furthermore, Trester has applied and experienced the usage of andragogical principles in his Biblical Andragogy Clinic. He asserts, "Biblical Andragogy is premised on the assumption that groups of adult learners are the richest potential source of creativity if they interact supportively, noncompetitively, and collaboratively." 46

After attending the two-week Facilitators Clinic of Mississauga, Canada, the participants testify,

42 Ronda, 27.

${ }^{43}$ Ibid., 22-23.

${ }^{44}$ Soeherman, 4.

${ }^{45}$ Knowles, M. S. \& Associates. Andragogy in Action: Applying Modern Principles of Adult Learning, 343.

${ }^{46}$ Eugene Trester, "The biblical andragogy clinic," in M. S. Knowles \& Associates (ed.), Androgogy in action: Applying modern principles of adult learning (p. 343-349). (San Fransisco, CA: Jossey-Bass, 1984), 349. 
We have participated in the development of a caring and respectful community. We were, more than we realized, a group of persons constantly nourishing each other as faith people. When zwe sang and prayed and reflected upon our studies, a sense of reality being a community in the Lord was established. This was a time when we all relaxed and unwound and were refreshed. Quite something when you also consider that our studies were serious business. ${ }^{47}$

Not only the participants of Biblical Andragogy Clinic gave their positive assessment, but also the biblical specialists in University of Toronto (Toronto School of Theology) recognized the positive impact of andragogical model of learning for Master of Divinity level. Their conclusion is, "[T] he adult's comprehension of the academic material attested positively and strongly to the competence of the learners and the power of the interdependent learning process." 48

Learning from Trester's report about his Biblical Andragogy clinic, I am convinced that andragogical principles are suitable for theological schools in Indonesia. As Knowles (1990) discuss that the Hebrew prophets and Jesus in Biblical times "were all teachers of adults, not of children," 49 as Christian educators in Indonesia we need to realize that even the Bible itself promotes Andragogy where learning has always taken place in communal setting.

In addition, one of the clergies in Indonesia that I interviewed, has been introducing a new Bible study method - Communal Discovery Manuscript Study - to Indonesian pastors and evangelists for two years. According to him, through this method, the adult learners discover the truth of a Bible passage together through discussion by asking and answering good questions and seeking Jesus together in His Word. The leader assists the group in digging into the passage rather than only the leader sharing insights and answering the group's questions. The method is not teaching but is community discovery. Maxey remarks, "It is unbelievable what happens when [adults] read the text (a couple pages), discuss it as a small group, and then discuss it in a bigger group. We do 80\% observation, $15 \%$ interpretation and 5\% application." ${ }^{50}$ When asked if this adult learning method can be utilized in theological schools in Indonesia, Maxey suggests,

\footnotetext{
${ }^{47}$ Eugene Trester, "The biblical andragogy clinic," in M. S. Knowles \& Associates (ed.), Androgogy in action: Applying modern principles of adult learning (p. 343-349). (San Fransisco, CA: Jossey-Bass, 1984), 349.

${ }^{48}$ Ibid., 349.

${ }^{49}$ M. S. Knowles, The adult leaner: A neglected species (4 ${ }^{\text {th }}$ ed.), 27.

${ }^{50}$ E. M., Interview by writer, December 7, 2011.
} 
We can start to use this method in the sophomore year so that the inductive approach to scripture would influence their whole education, but in first year maybe they are too immature. This learning approach can also be used as a method to teach other subjects instead of simply using the lecture format. If you did a manuscript study of Acts, you would learn church growth, early church history and the power of the Holy Spirit. ${ }^{51}$

This aforementioned method of adult learning definitely is appropriate for theological schools in Indonesia because Indonesian culture is a communal culture. Like other Asian cultures, "The nail that sticks up gets pounded down," 52 Indonesian people prefer to have an opinion or decision as a communal effort instead of individualistic performance. ${ }^{53}$

Most of the students in graduate programs in Indonesian theological schools are pastors or evangelists that have been in ministries for some time. I think that theological school can be excellent learning institutions if these experienced pastors are able to contribute their knowledge and life stories in their classes through discussion. As Knowles (1990) theorizes, "Experience is the richest resource for adult learning; therefore, the core methodology of adult education is the analysis of experience." 54

\section{Conclusion}

Knowles' educational theories of andragogy make the distinction between pedagogy and andragogy. European influences created a system of pedagogical methodology in Indonesian Christian theological education. Jane Vella's experience of applying Knowles' theories of andragogy in Indonesia shows that andragogy is, in fact, compatible and perhaps even preferable to current pedagogical methods.

It is time that theological schools in Indonesia understand the importance of andragogy for adult Christian education. In Indonesia, adults do not like the idea of Sunday school or school because they think Sunday school or school is for children and it is beneath their dignity. However, utilizing the andragogical methods described in this paper, adult can learn in a dignified manner. Instead of being lectured what to

\footnotetext{
${ }^{51}$ E. M., Interview by writer, December 7, 2011.

52 R. B. Gail, Japanese lessons: A year in a Japanese school through the eyes of an American anthropologist and her children (New York, NY: New York University Press, 1997), 78. 2006),

${ }^{53} \mathrm{~J}$. Forshee, Culture and customs of Indonesia (Westport, CT: Greenwood Press,

${ }^{54}$ M. S. Knowles, The adult leaner: A neglected species (4th ed.), 31.
} 
know as children would be, adults should realize that each one is an integral part of the learning process. Through respectful participation, each adult can learn through discovery as well as contribute insight to others.

Therefore, the mandate of our Great Teacher, Jesus Christ, "...teaching them to obey everything I have commanded you. And surely I am with you always, to the very end of the age" (Matthew 28:20, NIV), can truly be implemented in our ministries as Christian educators.

\section{References}

Brown, C. A Short History of Indonesia: The Unlikely Nation? Singapore: South Wind Productions, 2003.

Dixon, R. L. "The Role of The Teacher and Student in the Transmission of The Value of Responsibility In The Teaching/Learning Process In Indonesian Higher Education." Doctoral Dissertation, 1992. Retrieved from ProQuest Dissertations and Theses. (Accession Order No. AAT 9302774).

Forshee, J. Culture and Customs of Indonesia. Westport, CT: Greenwood Press, 2006.

Gail, R. B. Japanese Lessons: A Year in A Japanese School Through the Eyes of An American Anthropologist and Her Children. New York, NY: New York University Press, 1997.

Galbraith, M. W. (ed.), Adult learning methods: A guide for effective instruction. Malabar, FL: Roberte E. Krieger Pub., 1990.

Holt, R. A. "An Analysis of Contemporary Adult Learning Theories and The Implications for Teaching in The Local Church for Spiritual Maturity." Doctoral Dissertation. 2010. Retrieved from ProQuest Dissertations and Theses. (Accession Order AAT 3431780).

Jarvis, P. Adult Education and Lifelong Learning: Theory and Practice ( $3^{\text {rd }}$ Edition). New York, NY: Routledge Falmer, 2004.

Knowles, M. S. \& Associates. Andragogy in Action: Applying Modern Principles of Adult Learning. San Francisco, CA: Joessey-Bass Inc, 1984.

Knowles, M. S. The Adult Leaner: A Neglected Species ( $4^{\text {th }}$ ed.). Huston, TX: Gulf Publishing Company. 1990.

Knowles, M. S. The Modern Practice of Adult Education: Andragogy Versus Pedagogy. New York, NY: Association Press, 1970.

Knowles, M. S., Holton, E. F., \& Swanson, R. A. The Adult Learner: The Definitive Classic in Adult Education and Human Resource Development (6 $6^{\text {th }}$ Ed.). San Diego, CA: Elsevier, 2005.

Kolb, D. A. Experiential Learning: Experience As The Source of Learning And Development. Englewood Cliffs, NJ: Prentice Hall, 1984. 
Lindeman, E. C. The Meaning of Adult Education. New York, NY: New Republic, 1926.

Merriam, S. B., Caffarella, R. S., \& Baumgartner, L. M. Learning in Adulthood: A Comprehensive Guide. San Francisco, CA: Jossey-Bass, 2007.

Ronda, D. "The Perspectives of Students And Theological Educators on Good Teaching: A Look at Theological Education in Indonesia." Doctoral Dissertation, 2007. Retrieved from ProQuest Dissertations and Theses. (Accession Order No. AAT 3275109).

Soeherman, S. "The Relationships of Critical Thinking Skills, Critical Thinking Dispositions, And College Experiences of Theological Students in Indonesia." Doctoral Dissertation, 2010. Retrieved from ProQuest Dissertations and Theses. (Accession Order AAT 3448370).

Sorenson, H. Adult Abilities. Minneapolis, MN: University of Minnesota Press, 1938.

Thorndike, E. L. Adult Learning. New York, NY: Macmillan, 1928.

Knowles, M. S. \& Associates. Androgogy In Action: Applying Modern Principles Of Adult Learning. San Fransisco, CA: Jossey-Bass, 1984.

Vella, J. K. Learning to Listen, Learning to Teach: The Power of Dialogue in Educating Adults (Revised Edition). San Francisco, CA: Jossey-Bass, 2002.

Wilson, A. L., \& Burket, L. What Makes Learning Meaningful? 1989. ERIC, EBSCOhost (accessed December 8, 2011). 